\title{
Generation of a Mono-ubiquitinated PCNA Mimic by Click Chemistry
}

\author{
Silvia Eger, ${ }^{[a]}$ Benoît Castrec, ${ }^{[b]}$ Ulrich Hübscher, ${ }^{[b]}$ Martin Scheffner, ${ }^{[a]}$ Marina Rubini, ${ }^{*[a]}$ and \\ Andreas Marx*[a]
}

\begin{abstract}
Genotoxic stress results in more than 50000 damaged DNA sites per cell per day. During DNA replication, processive highfidelity DNA polymerases generally stall at DNA lesions and have to be displaced by translesion synthesis DNA polymerases, which are able to bypass the lesion. This switch is mediated by mono-ubiquitination of the processivity factor proliferating cell nuclear antigen (PCNA). To further investigate the regulation of the DNA polymerase exchange, we developed an easy and efficient method to synthesize site-specifical-
\end{abstract}

ly mono-ubiquitinated PCNA by click chemistry. By incorporating artificial amino acids that carry an azide (Aha) or an alkyne (PIk) in their side chains, into ubiquitin (Ub) and PCNA, respectively, we were able to link the two proteins site-specifically by the $\mathrm{Cu}^{\prime}$-catalyzed azide-alkyne cycloaddition. Finally, we show that the synthetic PCNA-Ub is able to stimulate DNA synthesis by DNA polymerase $\delta$, and that DNA polymerase $\eta$ has a higher affinity for PCNA-Ub than to PCNA.

\section{Introduction}

Proliferating cell nuclear antigen (PCNA) is a ring-shaped, homotrimeric protein that functions as a sliding clamp during DNA replication. It encircles the DNA and binds to replicative DNA polymerases (pols), for example, pol $\delta$, and enhances their processivity. ${ }^{[1]}$ When pol $\delta$, a high-fidelity DNA polymerase, encounters a DNA lesion on the template strand, DNA synthesis mostly stalls because pol $\delta$ is unable to bypass DNA lesions. As unwinding of the DNA double strand at the replication fork continues, a longer region of single-stranded (ss) DNA is formed. This ssDNA is covered by replication protein A (RPA) that recruits the ubiquitin (Ub)-conjugating enzyme, Rad6, and the Ub ligase, Rad18, to the site of the DNA damage. Subsequently, PCNA is ubiquitinated at Lys $164 .{ }^{[2]}$ This mono-ubiquitinated PCNA (PCNA-Ub) seems to be responsible for the recruitment of translesion synthesis (TLS) DNA polymerases, like pol $\eta$, pol $\mathrm{l}$, pol $\kappa$ and Rev1. TLS polymerases belong to the Y-family and are specialized to bypass several types of DNA lesions. ${ }^{[3]}$

In the last decade, many studies have investigated how TLS polymerases are recruited to the site of DNA damage and the role of PCNA-Ub in this process. It was found that TLS polymerases bind PCNA-Ub at two sites, at the interdomain connector loop of PCNA via their PCNA-interacting protein (PIP) domain and to Ub via their Ub-binding domain (UBD) ${ }^{[4]}$ All TLS polymerases contain a UBD, and mutations in this domain result in the inactivation of their function in lesion bypass. For pol $\eta$, binding to PCNA via its PIP domain seems to be a prerequisite for its ability to function in TLS; ${ }^{[7]}$ however, the importance of direct binding of the UBD to the Ub moiety on PCNA is discussed controversially. ${ }^{[4,6]}$ Mutational inactivation of the Ub-binding zinc finger (UBZ) domain indeed results in defects in pol $\eta$ function in TLS, in vivo. ${ }^{[4 b]}$ However, Acharya et al. reported that the UBZ domain makes no significant contribution to pol $\eta$ PCNA binding ability, and hypothesized that the adverse effect of some UBZ mutations on pol $\eta$ function in TLS, in vivo, results from effects unrelated to PCNA binding. ${ }^{[6]}$

In order to elucidate the role of mono-ubiquitination of PCNA, an efficient method to obtain PCNA-Ub, in vitro, is needed. Two separate studies have established the Rad6/ Rad18-dependent PCNA mono-ubiquitination reaction at Lys 164 with the use of purified yeast proteins. ${ }^{[7,8]}$ Both showed that in addition to the requirement for $\operatorname{Rad} 6 / \operatorname{Rad} 18$, the reaction depends on the loading of the PCNA homotrimeric ring onto DNA by replication factor C (RFC) and that all three PCNA monomers become efficiently ubiquitinated.

Recently, several nonenzymatic methods for site-specific ubiquitination of substrate proteins have been reported ${ }^{[9]}$ including oxime-based ligation ${ }^{[10]}$ and native chemical ligation. ${ }^{[11]}$ The Cu'-catalyzed Huisgen azide-alkyne cycloaddition (click reaction $)^{[12]}$ was used to form Ub dimers ${ }^{[13]}$ and to link Ub and several Ub-like proteins to a model protein. ${ }^{[14]}$ Mono-ubiquitination of PCNA was accomplished by a chemical approach based on disulfide exchange and intein chemistry. ${ }^{[15]}$ In another approach, means of producing mono-ubiquitinated PCNA by splitting the protein into two self-assembling polypeptides was developed. ${ }^{[16]}$

\footnotetext{
[a] S. Eger, Prof. Dr. M. Scheffner, Dr. M. Rubini, Prof. Dr. A. Marx Department of Chemistry, Department of Biology

Konstanz Research School Chemical Biology, University of Konstanz Universitätsstrasse 10, 78457 Konstanz (Germany)

E-mail: andreas.marx@uni-kontanz.de marina.rubini@uni-konstanz.de

[b] Dr. B. Castrec, Prof. Dr. U. Hübscher Institute of Veterinary Biochemistry and Molecular Biology University of Zürich, Winterthurerstrasse 190 8057 Zürich (Switzerland)
} 
Here, we present a straightforward and efficient method for site-selective ubiquitination of PCNA, which can be conducted by simple biochemical means with standard equipment without the need for eukaryotic cell culture or sophisticated solidphase synthesis. Similar to our protocol for the formation of site-selectively linked ubiquitin dimers ${ }^{[13]}$ we made use of artificial amino acids that carry an azide (Aha) and an alkyne (Plk) in their side chains, and can, therefore, be linked by the click reaction (Scheme 1). ${ }^{[17]}$
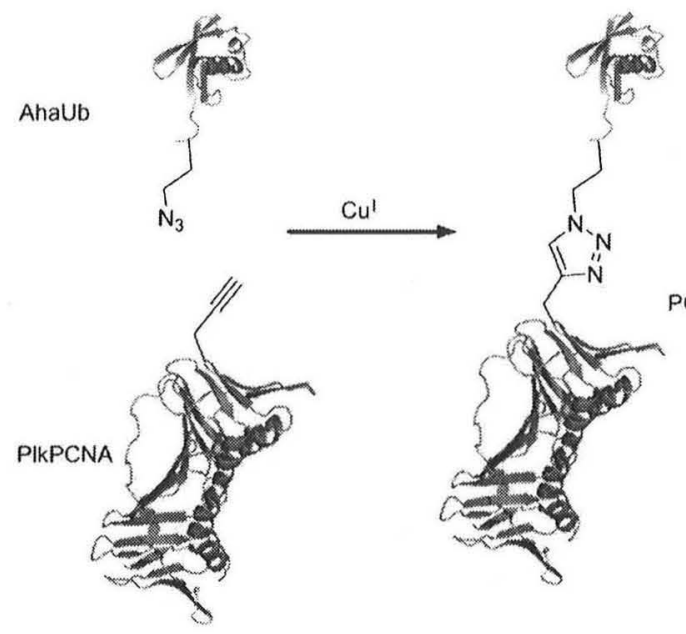

Scheme 1. Schematic representation of PCNA-Ub formation by click reaction between an azide-functionalized $\mathrm{Ub}$ (AhaUb) and an alkyne-functionalized PCNA (PIkPCNA); see main text for details.

\section{Results and Discussion}

\section{Incorporation of Aha}

Azidohomoalanine (Aha; Figure 1 A) is a methionine (Met) analogue, and as such, it can replace its natural counterpart in an appropriate Met auxotrophic E. coli strain. ${ }^{[18]}$ We introduced Aha at the $C$ terminus of Ub by substituting the codon for the C-terminal Gly by the ATG Met coding triplet. In addition, for reasons of purification we introduced an $\mathrm{N}$-terminal polyhistidine tag in which the initial Met/Aha is followed by glycine and serine, and which is, therefore, co-translationally removed by the methionine aminopeptidase (MetAP). The following coding sequence for Ub starts with Glu and skips the first Met. This is necessary, as only one azide at the $\mathrm{C}$ terminus of $\mathrm{Ub}$ is required for site-selective linkage to PCNA. The described construct (HisUb76M, Figure 1B) was expressed in Met auxotrophic E. coli B834(DE3). Cells were cultured under limiting Met concentration until they reached stationary growth. The growth medium was then switched to fresh minimal medium containing Aha and protein expression was induced. We were able to isolate the target protein with the initial amino acid quantitatively cleaved off and the C-terminal Met completely replaced by Aha, as confirmed by ESI-MS (Figure 1D-F). Interestingly, the purified protein sample contained two Ub species that differed in mass. One species had the expected mass of
A)<smiles>N#CCC(N)C(=O)O</smiles>

1 RIFVKTITG KTITTEVEPS

21. DTIENVKAKI. QDKEGI PPDQ

41. QRT, YFAGKOI, EDGRTYSDYM

61 TOKESTLHLV LRLRGM

G76M: GGT $\rightarrow$ ATG
B) MgsshHmhHssglvergs

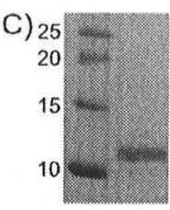

D)

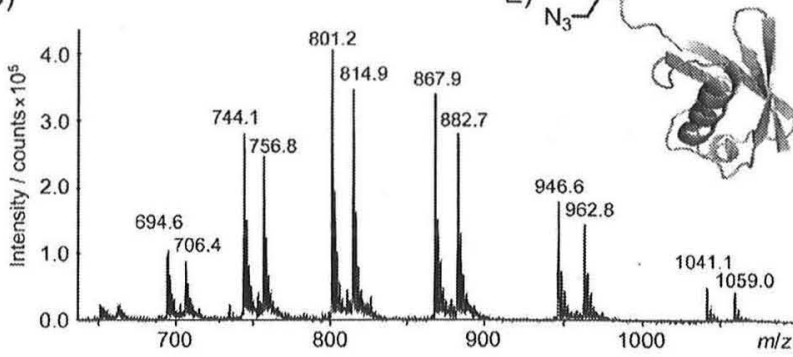

F)

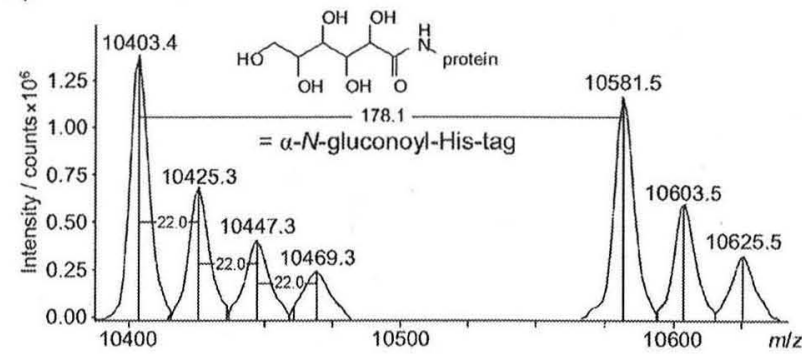

Figure 1. Expression of 76AhaUb: A) azidohomoalanine (Aha); B) amino acid sequence of HisUb76MUb; C) SDS-PAGE analysis of 76AhaUb; D) ESI-MS analysis of 76AhaUb; E) cartoon representation of 76AhaUb; and F) deconvoluted MS spectra of 76AhaUb (calcd 10397.9).

10403.4 Da (calcd 10397.9 Da), while the second one was 178.1 Da heavier. Having confirmed that the clone only contained the desired expression vector, and that both protein species actually were $\mathrm{Ub}$, we concluded that the extra mass of 178.1 Da must derive from spontaneous $\alpha-N$-6-phosphogluconoylation of the His-tag in E. coli, as described by Geoghegan et al.; this results in a 178.1 Da heavier Ub conjugate. ${ }^{[19]}$

\section{Incorporation of Plk}

Our second aim was to incorporate an alkyne functionality via the pyrrolysine analogue Plk (Figure 2A) at position 164 of PCNA. Pyrrolysine analogues can be incorporated in response to an amber stop codon UAG by a pyrrolysyl-tRNA synthetase/ tRNA $_{\text {CUA }}^{\text {Pyl }}$ pair from Methanosarcina barkeri in E. coli. ${ }^{[9,20]}$ Lys 164 in the wild type (wt) PCNA sequence was mutated to the amber stop codon TAG (Figure 2B). The gene for the pyrrolysine tRNA synthetase, pylS, was obtained from genomic DNA from M. barkeri and cloned into the vector pRSFduet. The gene for the pyrrolysine tRNA was synthesized together with the constitutive lipoprotein promoter, Ipp, and was cloned into the backbone of pET11a, which already contained the gene for PCNA ((164TAG)PCNA) in its multiple cloning site. Both vectors were co-transformed into E. coli BL21(DE3) for expression. With 


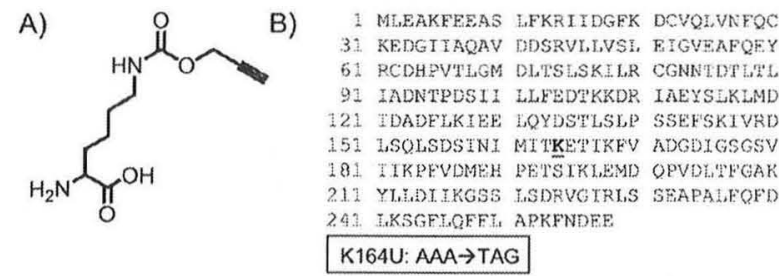

C)

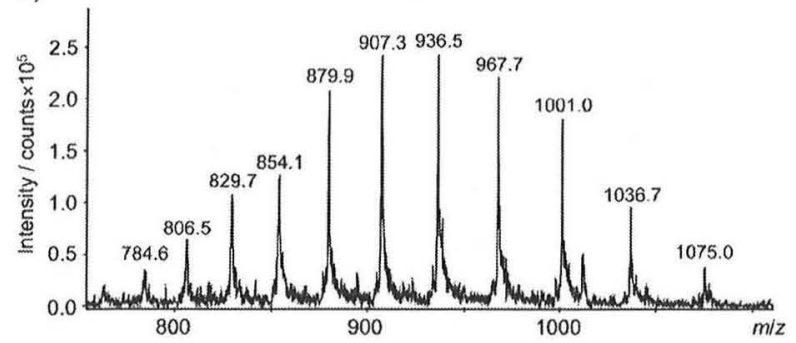

D)

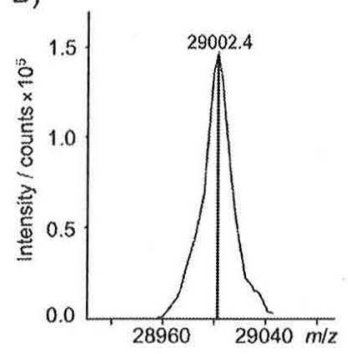

E)

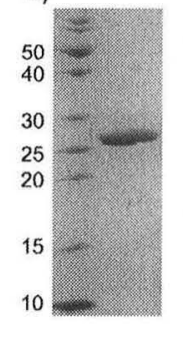

F)

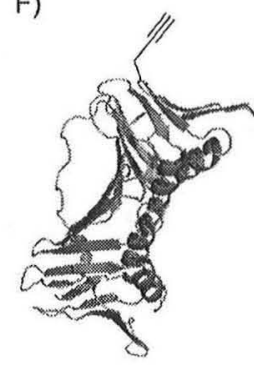

Figure 2. Expression of 164PIkPCNA: A) pyrrolysine analogue (PIk); B) amino acid sequence of PIkPCNA; C) ESI-MS and D) deconvoluted MS spectra of 164PIkPCNA (calcd 28998.2); E) SDS-PAGE analysis of 164PIkPCNA; F) cartoon representation of 164PIkPCNA.

this method, we were able to obtain 164PIkPCNA as confirmed by mass spectrometry (Figure 2C-F).

\section{Linking PCNA and Ub by the click reaction}

After purification of the two modified proteins, 76AhaUb and 164PIkPCNA were linked by the Cu'-catalyzed Huisgen azidealkyne cycloaddition. ${ }^{[14]}$ In this click reaction the azide and the alkyne of the two artificial amino acids react to form a stable triazole linkage. Analysis of the reactions by SDS-PAGE showed the formation of a new band at about $40 \mathrm{kDa}$ (Figure 3, lane 1), which was not detectable in the negative control experiment in which only one of the two click partners, either Ub or PCNA, was present (data not shown). As anticipated, this newly formed band stained positive in a Western blot with anti-Ub and anti-PCNA antibodies (data not shown). Trypsin digest of the $40 \mathrm{kDa}$ band followed by MS analysis confirmed the presence of the triazole linked peptide fragment (Figure 4). Subsequently, PCNA-Ub was purified from unreacted Ub by anion exchange chromatography (Figure 3, lane 2) and from unreacted PCNA by Ni-chelate affinity chromatography (Figure 3, lane 3).

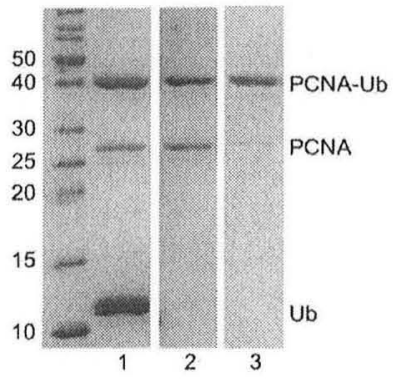

Figure 3. PCNA-Ub formation by click reaction. SDS-PAGE analysis of the click reaction between 76AhaUb and 164PIkPCNA (lane 1), after Q-Sepharose chromatography to separate the product from Ub (lane 2), and purified PCNA-Ub after Ni-NTA affinity chromatography to separate it from nonubiquitinated PCNA (lane 3).

$$
\begin{aligned}
& \begin{array}{lllllllllllll}
y_{18} y_{17} & y_{75} y_{14} & y_{13} & y_{12} & y_{11} & y_{10} & y_{9} & y_{8} & y_{7} & y_{6} & y_{5} & y_{4} & y_{3}
\end{array}
\end{aligned}
$$

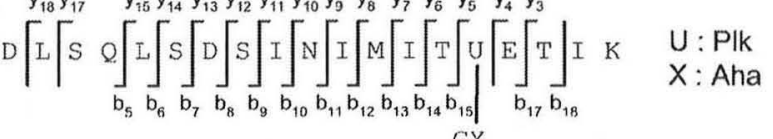

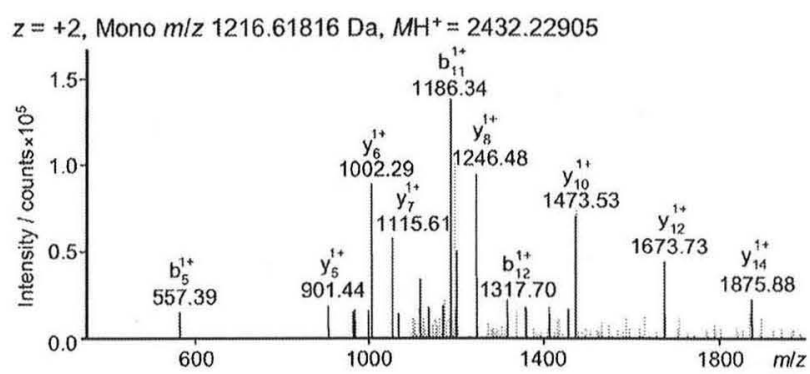

Figure 4. MS/MS spectrum of trypsin digested 164PIkPCNA-76AhaUb; all b and $y$ ions marked in the peptide sequence were found in the corresponding MS/MS spectrum.

\section{Stimulation of Pol $\delta$ by PCNA-Ub}

To determine if the synthetic PCNA-Ub is able to function as a processivity factor for pol $\delta$, we performed a template poly(dA)/primer oligo(dT)-based assay. ${ }^{[2]}$ In this assay, the amount of $\left[{ }^{3} \mathrm{H}\right] \mathrm{dTTP}$ incorporated opposite a poly $(\mathrm{dA})$ template by pol $\delta$ is measured. Activation of pol $\delta$ by PCNA was determined for different concentrations of PCNA compared to pol $\delta$ alone. In this assay, PCNA-Ub was able to activate pol $\delta$, albeit with a slightly lower activation potential than unmodified PCNA (Figure 5), suggesting that PCNA-Ub is functionally active.

\section{Higher affinity of Pol $\eta$ to PCNA-Ub than to PCNA}

At DNA lesions, PCNA is ubiquitinated at Lys $164^{[2]}$ and PCNAUb seems to be responsible for the recruitment of TLS DNA polymerases, like pol $\eta$. Pol $\eta$ contains two PCNA-interacting protein domains (PIP1 and PIP2) and two Ub-binding domains (UBM and UBZ), and therefore, shows a very high affinity to PCNA-Ub. ${ }^{[4,22]}$ As the affinity derives from the concerted binding to several different binding domains to PCNA and Ub, the 


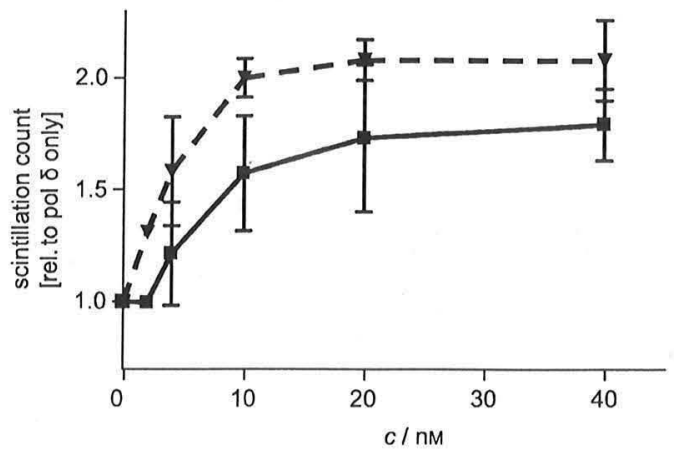

Figure 5. DNA synthesis assay with pol $\delta$. Stimulation of pol $\delta$ by unmodified (wt) PCNA (-- - -) and PCNA-Ub (- - - The TCA assay was performed according to ref. [20] $(n=3)$.

covalent linkage of PCNA and Ub is important for the high affinity.

To prove that pol $\eta$ has high affinity to our synthetic PCNAUb, we established a primer extension experiment. We used a circular template on which the circular, trimeric PCNA or PCNA-Ub cannot be loaded without the PCNA-loading factor, RFC. The results showed that in the absence of PCNA, pol $\eta$ was able to bind to the circular DNA template and elongate the labeled primer strand to the full-length product of $42 \mathrm{nu}$ cleotides (Figure 6B, lane $2,-$ ). Pol $\eta$ was even able to replace the primer strand and continue DNA synthesis along the circular template; this resulted in weak bands on the polyacrylamide gel with a size of more than 42 nucleotides (data not shown). Addition of PCNA did not alter the activity of pol $\eta$ (Figure $6 \mathrm{~B}$, lane $3, \mathrm{wt}$ ), while addition of the same amount of PCNA-Ub resulted in reduced DNA synthesis (Figure 6B, lane 4, PU). This can be explained by the high affinity of pol $\eta$ to PNCA-Ub, which in the described experiment was not loaded onto the DNA. Thus, pol $\eta$ bound to PCNA-Ub could not contribute to DNA synthesis.

We also confirmed that binding of PCNA-Ub to pol $\eta$ is dependent on the covalent linkage of PCNA and $\mathrm{Ub}$, as a mixture of free PCNA and Ub did not have an inhibitory effect (Figure $6 \mathrm{~B}$, lane $5, \mathrm{wt} / \mathrm{Ub}$ ). Furthermore, to exclude any unspecific inhibitory effect on DNA polymerases by PCNA-Ub, the experiment was repeated with DNA polymerase $\beta(\operatorname{pol} \beta)$. Pol $\beta$ is the key polymerase in base excision repair and is not known to interact with PCNA or PNCA-Ub, in vivo. ${ }^{[23]}$ Figure $6 \mathrm{C}$ shows that in the primer extension experiment pol $\beta$ was neither influenced by PCNA nor by PCNA-Ub. Altogether, the data strongly indicate that pol $\eta$ has a higher affinity to our synthetic PCNAUb than to PCNA.

\section{Conclusions}

In summary, with this work we have established a straightforward method that provides easy access to mono-ubiquitinated PCNA by copper-catalyzed click chemistry. The method requires standard biochemistry laboratory equipment, without the need for eukaryotic cell culture or sophisticated solidphase synthesis. Our results show that the ubiquitin-modified
A)

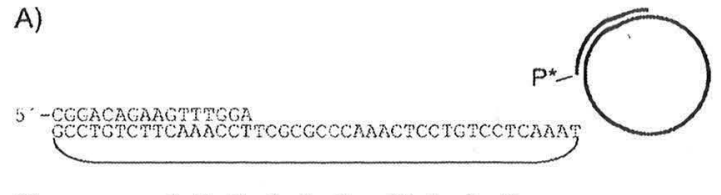

B)

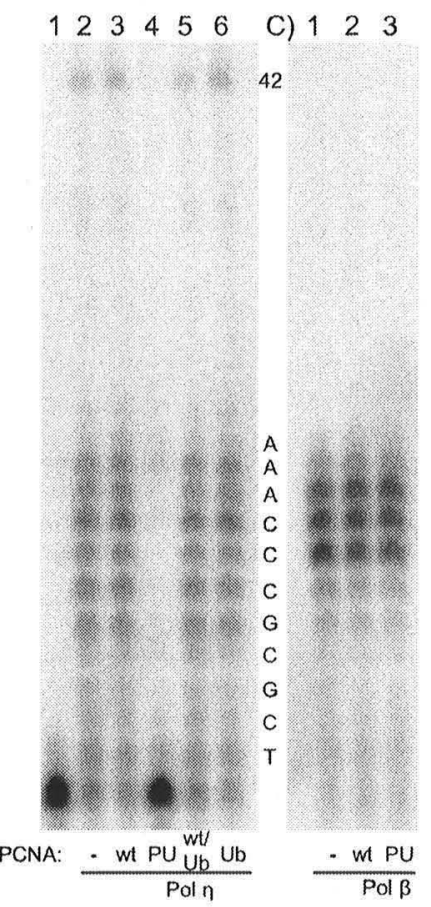

Figure 6. Primer extension studies with a circular template. A) Circular template, RCT42, with primer P16. PAGE analysis of primer extension experiments with: $B$ ) pol $\eta$, and C) pol $\beta$. PCNA-Ub (PU, $100 \mathrm{~nm}$, trimer) inhibits DNA synthesis of pol $\eta(B$, lane 4$)$ but not of pol $\beta$ (C, lane 3$)$. Inhibitory effect is observed by PCNA-Ub ( $B$, lane 4 ) but neither by PCNA ( $B$, lane 3, $100 \mathrm{~nm}$, trimer) or $\mathrm{Ub}$ alone $(B$, lane $6,300 \mathrm{~nm})$ nor by a mixture of both ( $B$, lane 5).

PCNA is able to stimulate DNA synthesis by pol $\delta$ albeit to a reduced extent compared to unmodified PCNA. Furthermore, we have confirmed a higher affinity of pol $\eta$ to PCNA-Ub than to PCNA. Thus, the method should be suited for further investigations on the role of PCNA-Ub in TLS.

\section{Experimental Section}

Chemical synthesis: All chemicals were of analytical grade and purchased from Sigma-Aldrich, ABCR or Bachem. NMR spectra were acquired on a Bruker Avance III $400 \mathrm{MHz}$ spectrometer with proton resonance frequencies of $400 \mathrm{MHz}$. Aha was prepared as previously described by Link et al..$^{[1]}$ The propargyl-protected lysine derivative, Plk, was prepared as described by Nguyen et al. ${ }^{[2]}$

Nutrient media: All expression experiments with Aha were performed in New Minimal Media (NMM). This was prepared from autoclaved $5 \times$ stock solutions of inorganic salts $\left(37.5 \mathrm{mM}\left(\mathrm{NH}_{4}\right)_{2} \mathrm{SO}_{4}\right.$ $42.5 \mathrm{~mm} \mathrm{NaCl}, 110 \mathrm{mM} \quad \mathrm{KH}_{2} \mathrm{PO}_{4}, 250 \mathrm{~mm} \mathrm{~K} \mathrm{HPO}_{4}, 5 \mathrm{~mm} \mathrm{MgSO}{ }_{4}$ $5 \mathrm{mgL}^{-1} \mathrm{CaCl}_{2}, 5 \mathrm{mg} \mathrm{L}^{-1} \mathrm{FeCl}_{2}, 5 \mu \mathrm{gL}^{-1} \mathrm{CuCl}_{2}, 5 \mu \mathrm{gL}^{-1} \mathrm{MnCl}_{21}$ $5 \mu \mathrm{g} \mathrm{L}^{-1} \mathrm{ZnCl}_{2}$ ). Sterile filtered glucose (final concentration $20 \mathrm{~mm}$ ), thiamine hydrochloride and D-biotin (final concentrations $10 \mathrm{mg} \mathrm{L}^{-1}$ ) were added. Finally, the media was supplemented with 
all natural amino acids ( $50 \mathrm{mg} \mathrm{L}^{-1}$ ) excluding methionine. All bacterial growth was under the selective pressure of carbenicillin $\left(100 \mathrm{mg} \mathrm{L}^{-1}\right)$.

Expression and purification of AhaUb: The gene coding for HisUb76M was synthesized by Geneart (Regensburg, Germany), and cloned into pGDR11 by using the restriction sites EcoRI and BamHI. For expression, the plasmid was transformed into Met auxotrophic E. coli B834(DE3). Cells were cultured in NMM with Met $(0.04 \mathrm{~mm})$ until they reached stationary growth $\left(\mathrm{OD}_{600}=0.8\right)$. Medium was then changed to fresh NMM supplemented with Aha $(0.5 \mathrm{~mm})$ and induced with IPTG $(1 \mathrm{~mm})$ after $30 \mathrm{~min}$. After $4 \mathrm{~h}$, cells were harvested by centrifugation and stored at $-80^{\circ} \mathrm{C}$ until further use. Pellets were resuspended in lysis buffer $(20 \mathrm{~mm}$ $\mathrm{Na}_{3} \mathrm{PO}_{4}, \mathrm{pH} 8,300 \mathrm{~mm} \mathrm{NaCl}$ ) and solubilized by sonication. Heating the suspension to $75^{\circ} \mathrm{C}$ for $20 \mathrm{~min}$ led to denaturation of most E. coli proteins. After being centrifuged at $20000 \mathrm{~g}$ for $20 \mathrm{~min}$ the supernatant was further purified by Ni-chelate affinity chromatography (Ni-IDA Sepharose).

Expression and purification of PlkPCNA: The gene coding for (164TAG)PCNA was synthesized by Geneart, and was cloned into PET11a by using the restriction sites Xbal and HindIII. The gene for the pyrrolysine tRNA synthetase (pylS) was obtained by PCR amplification of genomic DNA from M. barkeri, and was cloned into pRSFduet by using the restriction sites BfuAl and Sacl. The gene for the pyrrolysine tRNA was synthesized by Geneart together with the lipoprotein promoter, Ipp, and the terminator, $r r n C$, and cloned into the backbone of pET11a, which already contained the gene for (164TAG)PCNA in its multiple cloning site. Both vectors were co-transformed into $E$. coli BL21(DE3) for expression. Cells were cultured at $37^{\circ} \mathrm{C}$. At $\mathrm{OD}_{600}=0.3$, Plk $(1 \mathrm{~mm})$ was added. Protein expression was induced with IPTG $(1 \mathrm{mM})$ at $\mathrm{OD}_{600}=0.8$. After 12$16 \mathrm{~h}$, cells were harvested by centrifugation at $5000 \mathrm{~g}$, resuspended in lysis buffer (50 mM Tris- $\mathrm{HCl}, \mathrm{pH} 7.5,1 \mathrm{mM}$ EDTA, $0.2 \mathrm{mg} \mathrm{mL}^{-1} \mathrm{ly}$ sozyme, $0.5 \mathrm{~mm}$ PMSF, $5 \%$ glycerol) and incubated on ice for $30 \mathrm{~min}$. After addition of Igepal CA-630 (final concentration $0.02 \%$ ), cells were sonicated to complete disruption. Subsequently, ammonium sulfate (final concentration $150 \mathrm{~mm}$ ) and polyethyleneimine $(400 \mu \mathrm{L}$ of $5 \%$ ) were added to the cell lysate and stirred for $10 \mathrm{~min}$ before centrifugation at $15000 \mathrm{~g}$ for $40 \mathrm{~min}$. Additional ammonium sulfate $\left(0.23 \mathrm{~g} \mathrm{~mL}^{-1}\right)$ was added to the supernatant, and after being stirred for $1 \mathrm{~h}$ at room temperature, the suspension was centrifuged at $15000 \mathrm{~g}$ for $30 \mathrm{~min}$. The same procedure was repeated with ammonium sulfate $\left(0.24 \mathrm{~g} \mathrm{~mL}^{-1}\right)$ and the resulting pellet was resuspended in buffer $\mathrm{A}(20 \mathrm{~mL}, 20 \mathrm{~mm}$ Tris- $\mathrm{HCl}, \mathrm{pH} 7.5,20 \mathrm{~mm}$ $\mathrm{NaCl}, 1 \mathrm{~mm}$ EDTA, 5\% glycerol) and dialyzed, overnight, against buffer A containing DTT (1 $\mathrm{mM})$. The dialyzed protein was loaded onto a Q-Sepharose column and eluted by using a $\mathrm{NaCl}$ gradient of up to $1 \mathrm{M}$ in buffer $\mathrm{A}$. The fractions containing pure protein were pooled and dialyzed against buffer A with only $0.5 \mathrm{~mm}$ EDTA.

Click reaction: Different ratios of AhaUb and PlkPCNA in Tris- $\mathrm{HCl}$ $(20 \mathrm{~mm}, \mathrm{pH} 7.5), \mathrm{NaCl}(20 \mathrm{~mm})$, and glycerol (5\%) were mixed with TCEP $(1 \mathrm{~mm})$, TBTA $(10 \mu \mathrm{M})$ and $\mathrm{CuSO}_{4}(1 \mathrm{~mm})$. Reaction vessels were flushed with argon to prevent $\mathrm{Cu}$-induced protein oxidation. After incubation at room temperature for $1 \mathrm{~h}$ the reaction was stopped by addition of EDTA ( $10 \mathrm{~mm}$ ) and analyzed by SDS-PAGE. PCNA-Ub was purified from unreacted $U b$ by anion exchange chromatography in Tris- $\mathrm{HCl}(20 \mathrm{~mm}, \mathrm{pH} 7.5), \mathrm{NaCl}(20 \mathrm{~mm})$, glycerol $(5 \%)$, and DTT (1 mM), and from unreacted PCNA by Ni-chelate affinity chromatography. Fractions containing PCNA-Ub were pooled and dialyzed against PCNA storage buffer (20 mM Tris- $\mathrm{HCl}, \mathrm{pH} 7.5$, $20 \mathrm{~mm} \mathrm{NaCl}, 50 \%$ glycerol).
SDS-PAGE: Expressed proteins and click reactions were analyzed with glycine SDS-PAGE gels (15\%) according to standard procedures, and included stacking and resolving gels. Gels were stained by using Roti-Blue colloidal Coomassie, and were photographed by using ChemiDoc XRS (BioRad).

Mass analysis: ESI-IT mass spectra were recorded on a Bruker Daltonics Esquire $3000^{+}$. The protein samples were desalted with G25 columns (GE Healthcare) and diluted in acetic acid (2\%) in water/ $\mathrm{CH}_{3} \mathrm{CN}(1: 1)$. Samples were directly injected and data were analyzed with DataAnalysis from Bruker. For the analysis of the peptide fragments tryptic in-gel digest was conducted. After resolution of the resulting peptide fragments in formic acid $(0.2 \%)$ in water, we performed HPLC-ESI-MS/MS (Thermo Scientific LTQ Orbitrap Discovery). Data were analyzed by using DataAnalysis from Bruker and Mascot Search.

Poly(dA)/oligo(dT) assay: Pol $\delta$ and wtPCNA were expressed and purified as described. ${ }^{[21]}$ Pol $\delta(1 \mu \mathrm{L}, 150 \mathrm{~nm})$ and different concentrations of PCNA $(1 \mu \mathrm{L})$ or PCNA storage buffer as negative control were mixed on ice, and the reaction was started by addition of reaction mix $(23 \mu \mathrm{L})$ containing $1 \times$ reaction buffer $(50 \mathrm{~mm}$ Bis-Tris, pH 6.5, $1 \mathrm{~mm}$ DTT, $\left.0.25 \mathrm{mg} \mathrm{mL}^{-1} B S A, 6 \mathrm{~mm} \mathrm{MgCl}_{2}\right),\left[{ }^{3} \mathrm{H}\right] \mathrm{dTTP}$ $(25 \mu \mathrm{M})$, and poly(dA)/oligo(dT) ( $500 \mathrm{ng}$; all final concentrations in $25 \mu \mathrm{L}$ reaction volume). Reactions were incubated at $37^{\circ} \mathrm{C}$ for $30 \mathrm{~min}$ and then stopped by addition of sodium pyrophosphate $(100 \mu \mathrm{L}$ of $0.1 \mathrm{M})$ and ice-cold trichloroacetic acid $(1 \mathrm{~mL}, 10 \%, w / v)$. After being incubated on ice for $5 \mathrm{~min}$, the precipitate was collected on a Whatman GF/C filter, washed three times with $\mathrm{HCl}(1 \mathrm{M})$ containing sodium pyrophosphate $(0.1 \mathrm{M})$, rinsed with ethanol $(95 \%)$, and dried for $5 \mathrm{~min}$ under a heating lamp. The dry Whatman GF/C filter with the precipitate was transferred into a tube and toluene-based scintillation fluid $(5 \mathrm{~mL})$ was added. The radioactivity was measured in a liquid scintillation counter.

Primer extension studies: Pol $\eta$ was purchased from EnzyMax, LLC. Pol $\beta$ was expressed and purified as described. ${ }^{[24]}$ PCNA or PCNA-Ub (100 nm) and DNA polymerase (pol $\eta: 4 \mathrm{~nm}$, pol $\beta: 8 \mathrm{~nm}$ ) were mixed and reactions were started by adding the reaction mix containing template/primer $(2 \mathrm{nM}), 1 \times$ reaction buffer $(50 \mathrm{~mm}$ Tris$\left.\mathrm{HCl}, 0.25 \mathrm{mg} \mathrm{mL}^{-1} B S A, 1 \mathrm{mM} \mathrm{DTT}\right), \mathrm{MgCl}_{2}(5 \mathrm{~mm})$, and dNTPs $(10 \mu \mathrm{M})$ for pol $\eta$, and template/primer $(2 \mathrm{nM}), \mathrm{BSA}\left(0.1 \mathrm{mg} \mathrm{mL}^{-1}\right)$, $1 \times$ reaction buffer $(50 \mathrm{~mm}$ Tris- $\mathrm{HCl}, \mathrm{pH} 7.9,70 \mathrm{~mm} \mathrm{KCl}, 5 \%$ glycerol, $1 \mathrm{~mm}$ DTT), $\mathrm{MnCl}_{2}(2 \mathrm{~mm})$ and dNTPs $(15 \mu \mathrm{M})$ for pol $\beta$. The used primer was: 5'-CGGAC AGAAG ATTGGA-3', and the used circular template was: 5'-TAAAC TCCTG TCCTC AAACC CGCGC TTCCA AACTT CTGTC CG-3'. Elongation reactions (total volume $10 \mu \mathrm{L}$ ) were incubated at $37^{\circ} \mathrm{C}$ for $30 \mathrm{~min}$, and subsequently quenched by the addition of PAGE loading solution $(10 \mu \mathrm{L}, 80 \%, v / v$, formamide, $20 \mathrm{~mm}$ EDTA, $0.025 \%$, $w / v$, bromophenol blue, $0.025 \%, w / v$ xylene cyanol). Samples were denatured at $95^{\circ} \mathrm{C}$ for $5 \mathrm{~min}$, and analyzed with PAGE $(12 \%)$ containing urea $(8 \mathrm{M})$. Visualization was performed by using phosphorimaging.

\section{Acknowledgements}

We gratefully acknowledge funding by the Konstanz Research School Chemical Biology and the DFG. S.E. is grateful for a grant by the Boehringer Ingelheim Fonds. B.C. and U.H. are supported by Oncosuisse and the Swiss National Science Foundation. We thank Andreas Marquardt (Proteomics Facility, University of Konstanz) for expert assistance with mass spectrometry. 
Keywords: click chemistry - PCNA - protein engineering ubiquitin · unnatural amino acids

[1] a) C. K. Tan, C. Castillo, A. G. So, K. M. Downey, J. Biol. Chem. 1986, 261 12310-12316; b) R. Bravo, R. Frank, P. A. Blundell, H. Macdonald-Bravo, Nature 1987, 326, 515-517; c) G. Prelich, C. K. Tan, M. Kostura, M. B. Mathews, A. G. So, K. M. Downey, B. Stillman, Nature 1987, 326, 517 520.

[2] C. Hoege, B. Pfander, G.-L. Moldovan, G. Pyrowolakis, S. Jentsch, Nature 2002, 419, $135-141$.

[3] S. Prakash, R. E. Johnson, L. Prakash, Annu. Rev. Biochem. 2005, 74, $317-$ 353.

[4] a) B. S. Plosky, A. E. Vidal, A. R. Fernández de Henestrosa, M. P. McLenigan, J.P. McDonald, S. Mead, R. Woodgate, EMBO J. 2006, 25, $2847-$ 2855; b) M. Bienko, C. M. Green, N. Crosetto, F. Rudolf, G. Zapart, B. Coull, P. Kannouche, G. Wider, M. Peter, A. R. Lehmann, K. Hofmann, I. Dikic, Science 2005, 310, 1821-1824; c) C. Guo, T. S. Tang, M. Bienko, J. L. Parker, A. B. Bielen, E. Sonoda, S. Takeda, H. D. Ulrich, I. Dikic, E. C. Friedberg, Mol. Cell. Biol. 2006, 26, 8892-8900.

[5] L. Haracska, C. M. Kondratick, I. Unk, S. Prakash, L. Prakash, Mol. Cell 2001, 8, 407-415

[6] a) N. Acharya, A. Brahma, L. Haracska, L. Prakash, S. Prakash, Mol. Cell. Biol. 2007, 27, 7266-7272; b) N. Acharya, J.-H. Yoona, H. Galib, I. Unkb, L. Haracskab, R. E. Johnsona, J. Hurwitzc, L. Prakasha, S. Prakasha, Proc. Natl. Acad. Sci. USA 2008, 105, 17724-17729; c) N. Acharya, J. Yoon, J. Hurwitz, L. Prakash, S. Prakash, Proc. Natl. Acad. Sci. USA 2010, 107, $10401-10405$.

[7] P. Garg, P. M. Burgers, Proc. Natl. Acad. Sci. USA 2005, 102, 18361 18366.

[8] L. Haracska, I. Unk, L. Prakash, S. Prakash, Proc. Natl. Acad. Sci. USA 2006, 103, 6477-6482

[9] a) L. J. Martin, R. T. Raines, Angew. Chem. 2010, 122, 9226-9228; Angew. Chem. Int. Ed. 2010, 49, 9042-9044; b) C. P. R. Hackenberger, D. Schwarzer, Angew. Chem. 2008, 120, 10182-10228; Angew. Chem. Int. Ed. 2008, 47, 10030-10074; c) C. P. R. Hackenberger, ChemBioChem 2007, 8, $1221-1223$; d) E. M. Sletten, C. R. Bertozzi, Angew. Chem. 2009, 121, 7108-7133; Angew. Chem. Int. Ed. 2009, 48, 6974-6998; e) T. Kurpiers, H. D. Mootz, Angew. Chem. 2009, 121, 1757-1760; Angew. Chem. Int. Ed. 2009, 48, 1729-1731; f) S. Sommer, N. D. Weikart, A. Brockmeyer, P. Janning, H. D. Mootz, Angew. Chem. 2011, 123, 10062-10066; Angew. Chem. Int. Ed. 2011, 50, 9888-9892.

[10] A. Shanmugham, A. Fish, M. P. Luna-Vargas, A. C. Faesen, F. ElQualid, T. K Sixma, H. J. Ovaa, J. Am. Chem. Soc. 2010, 132, 8834-8835.

[11] a) R. K. McGinty, J. Kim, C. Chatterjee, R. G. Roeder, T. W. Muir, Nature 2008, 453, 812-816; b) X. Li, T. Fekner, J. J. Ottesen, M. K. Chan, Angew. Chem. 2009, 121, 9348-9351; Angew. Chem. Int. Ed. 2009, 48, 91849187; c) K. S. Ajish Kumar, M. Haj-Yahya, D. Olschewski, H. A. Lashuel, A. Brik, Angew. Chem. 2009, 121, 8234-8238; Angew. Chem. Int. Ed. 2009,
48, 8090-8094; d) L. A. Erlich, K. S. Ajish Kumar, M. Haj-Yahya, P. E. Dawson, A. Brik, Org. Biomol. Chem. 2010, 8, 2392-2396; e) K. S. Ajish Kumar, L. Spasser, L. A. Erlich, S. N. Bavikar, A. Brik, Angew. Chem. 2010, 122, 10347-10351; Angew. Chem. Int. Ed. 2010, 49, 9126-9131; f) S. Virdee, Y. Ye, D. P. Nguyen, D. Komander, J. W. Chin, Nat. Chem. Biol. 2010, 6, 750-757; g) S. Virdee, P. B. Kapadnis, T. Elliot, K. Lang, J. Madrzak, D. P. Nguyen, L. Riechmann, J. W. Chin, J. Am. Chem. Soc. 2011, 133, 10708-10711; h) K. S. Ajish Kumar, S. N. Bavikar, L. Spasser, T. Moyal, S. Ohayon, A. Brik, Angew. Chem. 2011, 123, 6261-6265; Angew. Chem. Int. Ed. 2011, 50, 6137-6141.

[12] a) R. Huisgen, Angew. Chem. 1963, 75, 604-637; Angew. Chem. Int. Ed. Engl. 1963, 2, 565-598; b) V. V. Rostovtsev, L. G. Green, V. V. Fokin, K. B. Sharpless, Angew. Chem. 2002, 114, 2708-2711; Angew. Chem. Int. Ed. 2002, 41, 2596-2599; c) C. W. Tornoe, C. Christensen, M. Meldal, J. Org. Chem. 2002, 67, 3057-3064

[13] S. Eger, M. Scheffner, A. Marx, M. Rubini, J. Am. Chem. Soc. 2010, 132, $16337-16339$

[14] N. Weikart, H. Mootz, ChemBioChem 2010, 11, 774-777.

[15] J. Chen, Y. Ai, J. Wang, L. Haracska, Z. Zhuang, Nat. Chem. Biol. 2010, 6, $270-272$.

[16] B. D. Freudenthal, L. Gakhar, S. Ramaswamy, M. T. Washington, Nat. Struct. Mol. Biol. 2010, 17, 479-484.

[17] A. J. de Graaf, M. Kooijman, W. E. Hennink, E. Mastrobattista, Bioconjugate Chem. 2009, 20, 1281-1295.

[18] a) K. L. Kiick, E. Saxon, D. A. Tirrell, C. R. Bertozzi, Proc. Natl. Acad. Sci. USA 2002, 99, 19-24; b) S. I. van Kasteren, H. B. Kramer, H. H. Jensen, S. J. Campbell, J. Kirkpatrick, N. J. Oldham, D. C. Anthony, B. G. Davis, Nature 2007, 446, 1105-1109.

[19] K. F. Geoghegan, H. B. F. Dixon, P. J. Rosner, L. R. Hoth, A. J. Lanzetti, K. A. Borzilleri, E. S. Marr, L. H. Pezzullo, L. B. Martin, P. K. LeMotte, A. S. McColl, A. V. Kamath, J. G. Stroh, Anal. Biochem. 1999, 267, 169-184.

[20] a) E. Kaya, K. Gutsmiedl, M. Vrabel, M. Müller, P. Thumbs, T. Carell, ChemBioChem 2009, 10, 2858-2861; b) T. Fekner, X. Li, M. M. Lee, M. K. Chan, Angew. Chem. 2009, 121, 1661-1663; Angew. Chem. Int. Ed. 2009, 48, $1633-1635$.

[21] B. van Loon, E. Ferrari, U. Hübscher, Methods Mol. Biol. 2009, 521, 345359.

[22] P. L. Kannouche, J. Wing, A. R. Lehmann, Mol. Cell 2004, 14, 491-500.

[23] S. H. Wilson, W. A. Beard, D. D. Shock, V. K. Batra, N. A. Cavanaugh, R. Prasad, E. W. Hou, Y. Liu, K. Asagoshi, J. K. Horton, D. F. Stefanick, P. S. Kedar, M. J. Carrozza, A. Masaoka, M. L. Heacock, Cell. Mol. Life Sci. 2010, 67, 3633-3647.

[24] S. Gieseking, K. Bergen, F. di Pasquale, W. Welte, K. Diederichs, A. Marx, J. Biol. Chem. 2011, 286, $4011-4020$. 